\title{
Effect of strain and stocking density on thermo- physiological traits of broiler chickens raised in Nigeria
}

\author{
Popoola M. A. ${ }^{1 \star}$, Odukoya S. O. ${ }^{1}$, Olaniyi T. A. ${ }^{1}$, Tiamiyu A. K. ${ }^{2}$ and Adekunle O. F. ${ }^{1}$ \\ ${ }^{1}$ Federal College of Animal Health and Production Technology, Moor Plantation, Ibadan, Nigeria. \\ ${ }^{2}$ Institute of Agricultural Research and Training, Moor Plantation, Ibadan, Nigeria. \\ *Corresponding author. Email: herbyolar@gmail.com
}

Copyright @ 2017 Popoola et al. This article remains permanently open access under the terms of the Creative Commons Attribution License 4.0, which permits unrestricted use, distribution, and reproduction in any medium, provided the original work is properly cited.

Received 20th August, 2017; Accepted 25th September, 2017

\begin{abstract}
The study was conducted to assess the effect of strain and stocking density on thermo-physiological response of broiler chickens. A total number of two hundred and sixteen (216) day old broiler chicks consisting of three different strains were used for the experiment. These strains were: Marshall, Ross and Abor-acre. The birds were randomly allotted to three different stocking densities which were 10, 12 and $14 \mathrm{birds} / \mathrm{m}^{2}$ respectively. Each treatment group was replicated twice in a $2 \times 3$ factorial design. Data were collected on thermo-physiological traits of the chickens twice in a week to avoid undue stress on the birds. Data were also collected on ambient temperature and relative humidity of the experimental area. Traits measured were; rectal temperature, pulse rate and respiratory rate. The data were subjected to analysis of variance (ANOVA) and there was significant interaction effect of strain and stocking density on physiological traits of the chicken. Thus, it is recommended that Marshall broiler chicken can be raised on stocking density of 14 birds $/ \mathrm{m}^{2}$.
\end{abstract}

Keywords: Humidity, physiology, strain, temperature, traits.

\section{INTRODUCTION}

Poultry production is considered to be one of the most popular options in Nigeria in reducing the incidence of malnutrition particularly protein deficiency in the diets of populace (Obasoya et al., 2005). At present, there is an improvement in potential of broiler strains to provide high quality meat at lower cost (Kamp and Kenny, 2003). Broiler chickens are homoeothermic; they maintain their central body temperature within a slight range irrespective of ambient temperature (Furlan and Macari, 2002).

In broiler production, stocking density, which is floor space per chicken, is an important welfare factor. Factors to consider when determining stocking density include but are not limited to bird size, feeder space, drinker space, house dimension, bird welfare, nutrition, breed, performance and economic return (Ain Bazin et al., 1996). The ultimate goal is to maximize pounds of chicken produced per square foot while preventing production losses due to overcrowding (Belay and Tetter,
1996). Heat sensitivity increases at higher stocking density of chickens, increased temperature of litter and limited circulation of air around chickens. Stocking densities indirectly influences the creation of micro climate in the facility and forming of other environmental factors (Etches et al., 1995). When environmental temperature is the same as body temperature of birds, non-evaporative heat loss fails and heat can only be lost through increased respiration (Ahmad and Sarwar, 2006). Thus, this study assessed the effect of strain and stocking density on thermo-physiological responses of broiler chickens.

\section{MATERIALS AND METHODS}

\section{Experimental location}

The study was conducted in Teaching and Research 
Table1. Effect of strain on thermo-physiological traits of broiler chickens.

\begin{tabular}{lccc}
\hline Variables & Arbore acres & Marshall & Ross \\
\hline Rectal Temperature $\left({ }^{\circ} \mathrm{C}\right)$ & $42.50 \pm 0.48^{\mathrm{a}}$ & $42.58 \pm 0.89^{\mathrm{a}}$ & $41.76 \pm 0.01^{\mathrm{b}}$ \\
Pulse Rate (beats $/ \mathrm{min})$ & $197.07 \pm 0.54^{\mathrm{a}}$ & $197.50 \pm 0.50^{\mathrm{a}}$ & $189.49 \pm 1.60^{\mathrm{b}}$ \\
Respiratory Rate (breathes $/ \mathrm{min})$ & $61.66 \pm 0.71$ & $61.23 \pm 2.26$ & $58.11 \pm 0.68$ \\
\hline
\end{tabular}

a.b Means of different superscripts along the same row are significantly different $(p<0.05)$.

Farm of Federal College of Animal Health and Production Technology, Ibadan, Nigeria. Ibadan is the capital city of Oyo State and the third largest metropolitan area by population in Nigeria after Lagos and Kano with a population of over 3 million. The city has coordinates of $7^{\circ} 24^{\prime} 7.0632 " \mathrm{~N}$ and $3^{\circ} 55^{\prime} 2.3268^{\prime \prime} \mathrm{E}$. It has a tropical wet and dry climate with a lengthy wet season and relatively constant temperature throughout the course of the years. The mean total rainfall for Ibadan is 1420.06 $\mathrm{mm}$ while the mean maximum temperature is $26.46{ }^{\circ} \mathrm{C}$, minimum $21.42^{\circ} \mathrm{C}$ and the relative humidity is $74.55 \%$.

\section{Experimental design}

A total number of two hundred and sixteen (216) 0ne-day old broiler chicks consisting of three different strains (: Marshall, Ross and Abor-acre) were used for the experiment. The birds were randomly allotted to three different stocking densities which were 10, 12 and 14 birds $/ \mathrm{m}^{2}$ respectively. Each treatment group was replicated twice in a $2 \times 3$ factorial design. The study lasted for eight weeks. The dimension of each pen was $2.01 \times 1.00 \mathrm{~m}$ and was constructed in a way as to permit straight-through ventilation. The birds were fed commercial broiler feed ration $(2900 \mathrm{kcal} / \mathrm{kgME}$ and $20.00 \%$ Crude protein). Fresh feed and clean water were supplied ad-libitum. The feeders and drinkers were served proportionately depending on number of birds per treatment. Vaccination schedule and other management practices were strictly adhered to.

\section{Data collection and statistical analysis}

Data were collected on thermo-physiological traits of the chickens twice in a week to avoid undue stress on the birds. Traits measured were: rectal temperature, pulse rate and respiratory rate. Rectal temperature of the birds was measured with the aid of a digital thermometer (accuracy of \pm 0.1 and range of measurement of $42^{\circ} \mathrm{C}$ ). The digital thermometer was inserted into cloaca of the birds, which was slightly bent to a side when inserted into the cloaca of the chicken so as to avoid measuring the faecal temperature. The thermometer was put in place for 20 seconds and was withdrawn to take the readings
(Thwaites et al., 1990). Pulse rate was measured from the tarsus region of the chicken with the aid of a stethoscope. The stethoscope was placed on the tarsus bone and the pulse rate was recorded after 60 seconds. Respiratory rate was recorded as the number of frequency of breath movement of chicken per 20 seconds and later calculated as breathes per minute (Thwaites et al, 1990). Ambient temperature and relative humidity were measured with the aid of a thermo-hygrometer. The instrument was hung at a side on the wall of the pen at the height of the chickens. The readings were taken at an hour interval.

Data were subjected to analysis of variance (ANOVA) using SAS (v. 9.13) (SAS, 2004), where significant differences occurred in the means, the means were separated using Duncan Multiple Range Test.

\section{RESULTS}

Table 1 shows the effect of strain on the thermophysiological traits of broiler chickens. Result shows that rectal temperature and pulse rate of the chickens were significantly affected by strain $(p<0.05)$. Marshall chicken strain had the highest rectal temperature and pulse rate, this was closely followed by Arbore acre strain and the least values were obtained in Ross chicken. However, respiratory rate of the chicken was not significantly affected by the strain $(p>0.05)$. The highest respiratory rate was observed in Arbore acres and this is followed by Marshall.

The effect of stocking density on thermo-physiological traits of broiler chicken is presented in Table 2. Result shows that there were significant effects $(p<0.05)$ of stocking density on pulse rate and respiratory rate of the broiler chickens. Highest pulse rate was obtained in birds raised on stocking density of $14 \mathrm{birds} / \mathrm{m}^{2}$ and highest respiratory rate was recorded in chickens on stocking density of $10 \mathrm{birds} / \mathrm{m}^{2}$. However, there was no significant effect $(p>0.05)$ of stocking density on rectal temperature of the broiler chickens.

The ambient temperature and relative humidity recorded during the cool and hot hours of the day of the experimental period is presented in Figure 1. Temperature during the cool periods of the day was constant from day 28 to day 42 , which increased slightly 
Table 2. Effect of stocking density on the thermo-physiological traits of broiler chicken.

\begin{tabular}{lccc}
\hline Variables & $\mathbf{1 0} \mathbf{~ B i r d s} / \mathbf{m}^{\mathbf{2}}$ & $\mathbf{1 2} \mathbf{~ B i r d s} / \mathbf{m}^{\mathbf{2}}$ & $\mathbf{1 4} \mathbf{~ B i r d s} / \mathbf{m}^{\mathbf{2}}$ \\
\hline Rectal Temperature $\left({ }^{\circ} \mathrm{C}\right)$ & $42.42 \pm 0.49$ & $41.75 \pm 0.02$ & $42.68 \pm 0.89$ \\
Pulse Rate (beats $/ \mathrm{min})$ & $192.51 \pm 1.41^{\mathrm{b}}$ & $194.59 \pm 1.02^{\mathrm{ab}}$ & $196.96 \pm 0.45^{\mathrm{a}}$ \\
Respiratory Rate (breathes $/ \mathrm{min})$ & $57.34 \pm 69^{\mathrm{b}}$ & $62.79 \pm 2.24^{\mathrm{a}}$ & $60.87 \pm 0.76^{\mathrm{ab}}$ \\
\hline
\end{tabular}

${ }^{a . b}$ Means of different superscripts along the same row are significantly different $(p<0.05)$.

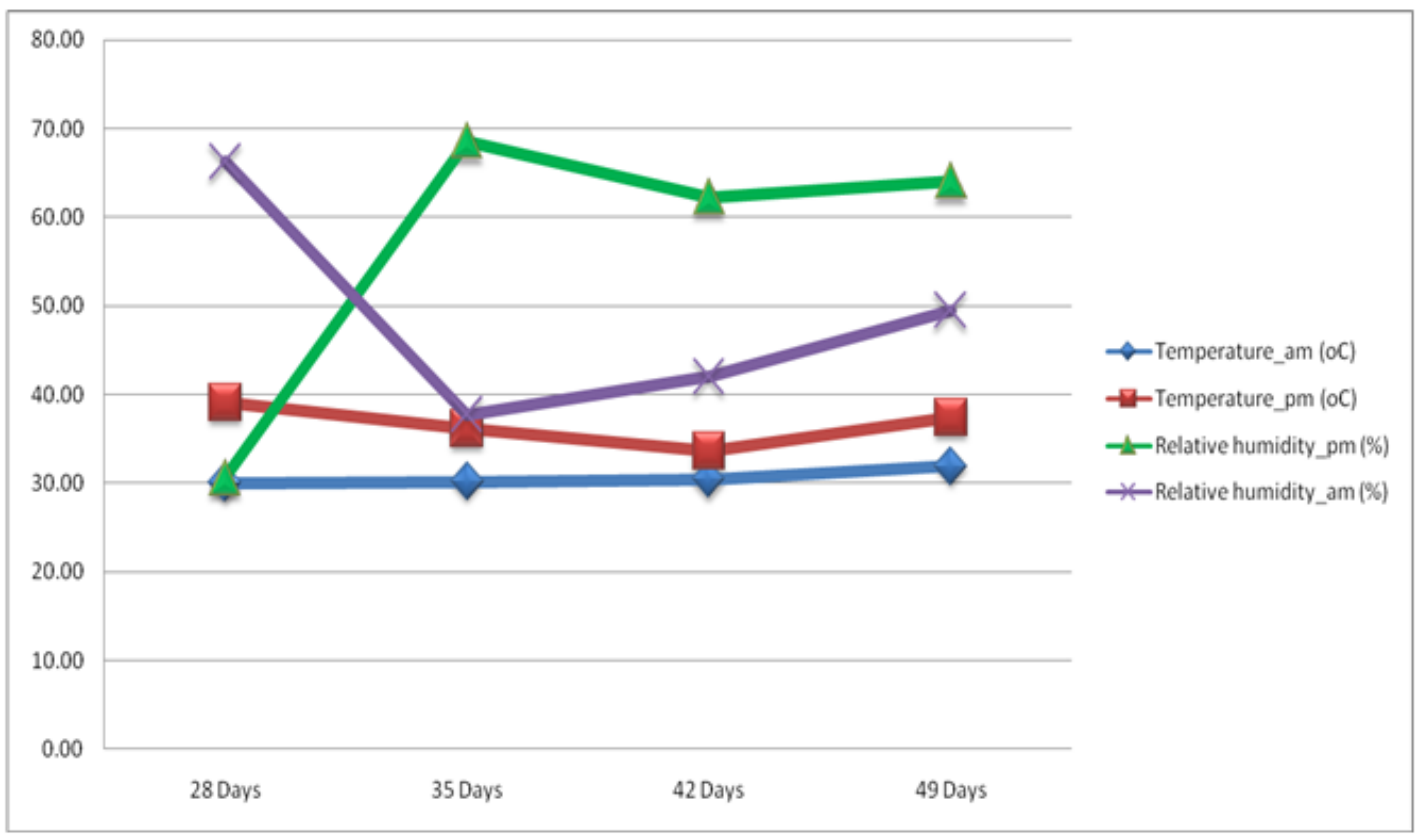

Figure 1. Environmental temperature and relative humidity during the cool and hot hours of the day.

from day 42 to day 49 (from $30^{\circ} \mathrm{C}$ to $33^{\circ} \mathrm{C}$ ). Also temperature during the hot periods of the day, at day 28 decreased continuously till day 42 (from 40 to $34^{\circ} \mathrm{C}$ ) and then increased slightly till day 49 (from 34 to $38^{\circ} \mathrm{C}$ ). Figure 2 also shows readings for relative humidity of the environment. The relative humidity during the hot periods of the day increased continuously from day 28 to day 49 (from 30 to $68 \%$ ). It decreased slightly from day 35 to day 42 (from 68 to $62 \%$ ) then increased slightly from day 42 to day 49 (62 to $65 \%)$. Also, relative humidity during the cool hours of the day decreased from day 28 to day 35 (67 to $38 \%$ ) and then it continued to increase from day 35 to day 49 (38 to $50 \%)$

The interaction effect of the strain and stocking density on the thermo-physiological traits of broiler chicken is presented in Table 3. Result shows that there was a significant interaction effect $(p<0.05)$ of strain and stocking density on the broiler chicken. Highest rectal temperature was recorded in Marshall raised on 14 birds $/ \mathrm{m}^{2}$. Ross raised on $12 \mathrm{birds} / \mathrm{m}^{2}$ had the highest pulse rate and highest respiratory rate was obtained in
Marshall raised on 12 birds $/ \mathrm{m}^{2}$.

\section{DISCUSSION}

The significant interaction effects of strain and stocking density on the chickens is an indication of response of these chickens to environmental factors based on differences in their strains. Kristensen et al. (2000) and Wathes (2002) reported that preening in chicken is associated with both high environmental temperatures and relative humidity. Freeman (1971) also reported that panting is the main mechanism of active heat dissipation. It is activated when the passive heat loss is not sufficient to keep the body temperature on its normal level. Mclean et al., (2001) also found deep panting of commercial broilers under moderate climate conditions from stocking densities of $34 \mathrm{~kg} / \mathrm{m}^{2}$ onwards. In the present study, panting increases as stocking density increases. Also, there is significant relationship between environmental temperature and panting. This is as a result of thermo- 


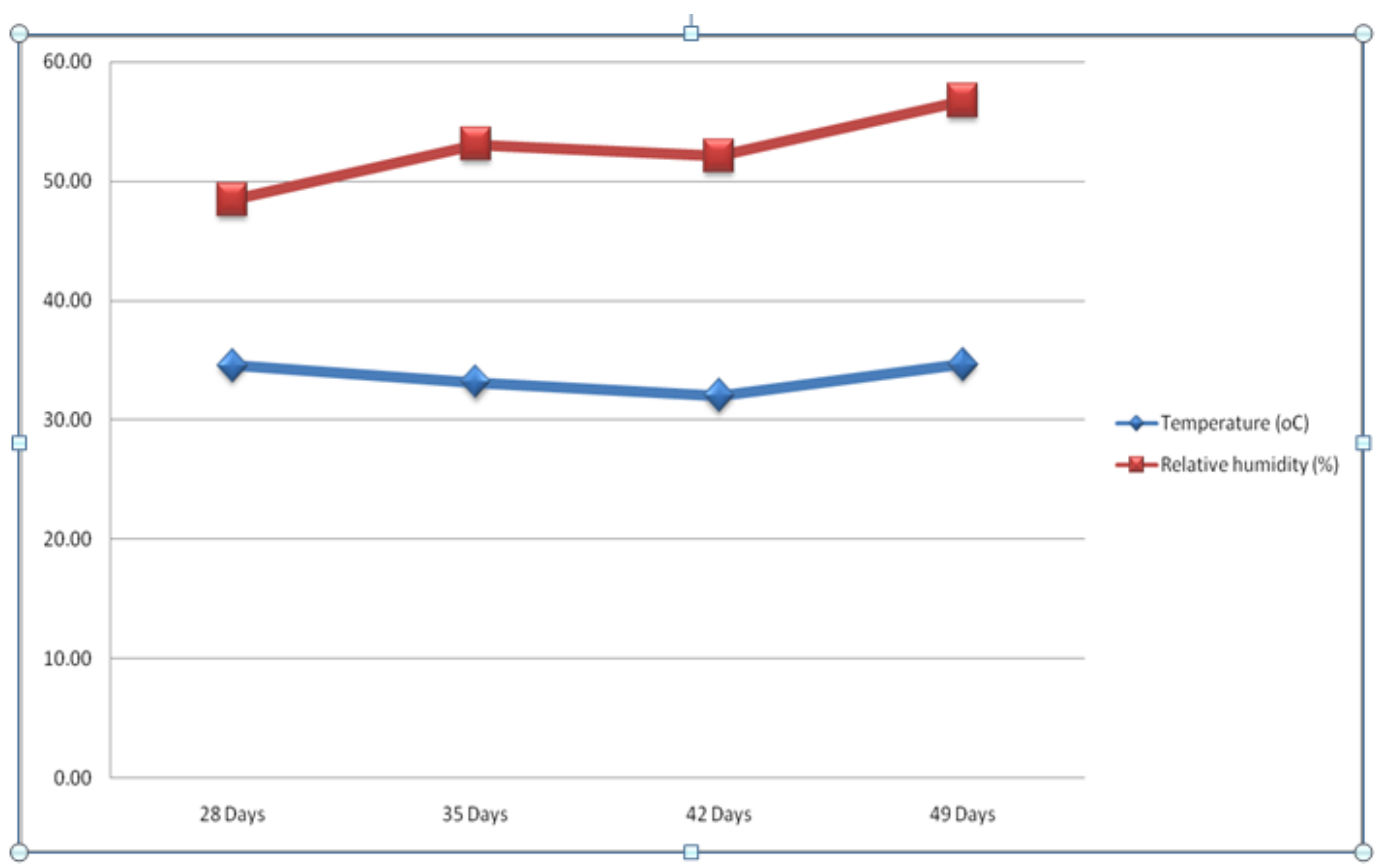

Figure 2. Temperature and relative humidity of the environment.

Table 3. Interaction effects of genotype and stocking density on thermophysiological traits of broiler chickens.

\begin{tabular}{|c|c|c|c|c|c|c|c|c|c|}
\hline \multirow{2}{*}{ Traits } & \multicolumn{3}{|c|}{ Abor acre } & \multicolumn{3}{|c|}{ Marshal } & \multicolumn{3}{|c|}{ Ross } \\
\hline & 10 birds $/ \mathrm{m}^{2}$ & 12 birds $/ \mathrm{m}^{2}$ & $14 \mathrm{birds} / \mathrm{m}^{2}$ & $10 \mathrm{birds} / \mathrm{m}^{2}$ & 12 birds $/ \mathrm{m}^{2}$ & 14 birds $/ \mathrm{m}^{2}$ & $10 \mathrm{birds} / \mathrm{m}^{2}$ & 12 birds $/ \mathrm{m}^{2}$ & 14 birds $/ \mathrm{m}^{2}$ \\
\hline Rectal temperature $\left({ }^{\circ} \mathrm{C}\right)$ & $43.85 \pm 1.45^{\mathrm{a}}$ & $41.81 \pm 0.02^{b}$ & $41.84 \pm 0.03^{b}$ & $41.68 \pm 0.04^{b}$ & $41.66 \pm 0.03^{b}$ & $44.41 \pm 2.67^{a}$ & $41.72 \pm 0.03^{b}$ & $41.78 \pm 0.02^{b}$ & $41.79 \pm 0.03^{b}$ \\
\hline Pulse rate (beats $/ \mathrm{min}$ ) & $197.54 \pm 1.23^{\mathrm{a}}$ & $196.63 \pm 0.77^{a}$ & $196.94 \pm 0.74^{\mathrm{a}}$ & $197.33 \pm 0.91^{\mathrm{a}}$ & $197.94 \pm 0.80^{a}$ & $197.23 \pm 0.80^{\mathrm{a}}$ & $182.65 \pm 3.60^{\mathrm{b}}$ & $189.10 \pm 2.75^{b}$ & $196.71 \pm 0.77^{\mathrm{a}}$ \\
\hline Respiratory rate (breathes/min) & $57.69 \pm 0.97^{c}$ & $64.31 \pm 1.12^{\mathrm{a}}$ & $62.98 \pm 1.43^{\mathrm{a}}$ & $55.98 \pm 1.34^{c}$ & $66.06 \pm 6.50^{\mathrm{a}}$ & $61.64 \pm 1.28^{\mathrm{b}}$ & $58.33 \pm 1.24^{c}$ & $58.02 \pm 1.16^{c}$ & $57.98 \pm 1.17^{c}$ \\
\hline
\end{tabular}

a.bmeans of different superscripts along the same column are significantly different $(p<0.05)$.

physiological responses of these chickens to both genotypic effects and environmental effects (stocking density).

\section{Conclusion}

Based on the result of this study, it can be concluded that there was significant interaction of strain and stocking densities on the broiler chicken. Thus, it is recommended that Marshall 
broiler chicken can be raised on stocking density of 14 birds $/ \mathrm{m}^{2}$

\section{CONFLICT OF INTEREST}

The authors declare that they have no conflict of interest.

\section{REFERENCES}

Ahmad, T., \& Sarwar, M. (2006). Dietary electrolyte balance: implications in heat stressed broilers. Worlds Poultry Science Journal, 62(4), 638-653.

Ain Bazin, H., Geraert, P. A., Padilha, J. C. F, \& Guillaumin, S. (1996). Chronic heat exposure enhances fat deposition and modifies muscle and fat partition in broiler carcasses. Poultry science, 75, 505-513.

Belay, T., \& Teeter, R. G. (1993). Broiler water balance and thermo-balance during thermo-neutral and high ambient temperature exposure. Poultry Science, 72, 116-124.

Etches, R. J., John, I. M., \& Gibbins, A. M. V. (1995). Behavioural, physiological, neuroendocrine and molecular responses to heat stress. In: Poultry production in hot climates. CAB International Wallingford UK, Pp. 31-65.

Furlan, R. L., \& Macari, M. (2002). Air velocity and exposure time to ventilation affect body surface and rectal temperature of broiler chickens. J. Appl. Poultry Res., 9(1), 1-5.
Freeman, B. M. (1971). Body temperature and thermoregulation. In. Bell, D. J., \& Freeman, B. M. (Eds), Physiology and Bio-chemistry of domestic fowl. Academic press, London. Pp. 1115-1151.

Kamp, C., \& Kenny, M. (2003). Feeding the modern broiler for more. International Hatchery Practice, 17, 11-13.

Mclean, J., Savory, J., \& Sparks, N. (2001). Welfare of male and female chickens in relation to stocking density. In proc 6th Europe. Symposium on poultry welfare, Zollikafen, Switzerland. Pp. 234-242.

Obasoya, D. O., Bamgbose, A. M., \& Omoikhoje, S. O. (2005). Blood profile of broilers fed diets containing different animal protein feedstuff. 10th Annual Conference on Animal Science Association of Nigeria. University of Ado - Ekiti, Nigeria, Pp. 176-178.

SAS (2004). Statistical analysis user's guide (release 8.03), SAS institute cary North Carolina, USA.

Thwaites, C. J. (1990). Physiology responses and productivity in sheep. In Yousef M.K. (Ed), Stress Physiology in Livestock CRC Press, Inc., Boca Raton, Florida, USA, Pp. 25-39.

Kristensen, H. H., Burjess, L. R., Demmers, T. G. H., \& Wathes C. M. (2000). The preferences of laying hens for different concentrations of atmospheric ammonia. Applied Behaviour Science, 68, 307-318.

Wathes, C. M. (2002). Measuring and auditing broiler welfare. Weeks, C. A., Butterworth, A. (Eds), CABI Publishing UK. Pp. 117-131. 